\title{
4
}

\section{Aboriginal guides in the Hunter Valley, New South Wales}

\author{
Mark Dunn
}

On 21 March 1820, John Howe from Windsor sent a message to Governor Macquarie from his camp at Wallis Plains on the Hunter River, by his calculations approximately 132 miles $(212 \mathrm{~km})$ overland north-north-west from Sydney. ${ }^{1}$ Howe wrote, 'I embrace the earliest opportunity to inform your Excellency that I reached the River on Wednesday last' and that 'in our way down the river we came through as fine a country as imagination can form'. ${ }^{2}$ For his trouble, Howe and the free men in his company were granted land along the river they had 'discovered', establishing themselves on the alluvial flood plains around the future town of Singleton. This story of discovery is well known to scholars of the Hunter Valley's colonial history. What is less well known is that Howe's success came after at least two earlier attempts by others to find a route between the Hawkesbury district and the upper Hunter Valley, and that he would not have succeeded at all without the assistance of his Aboriginal guides, Myles, Mullaboy, Murphy, Whirle and Bandagran.

1 Travelling on the modern Putty Road, which closely follows Howe's route from Windsor to the Hunter Valley, the distance between Windsor and Maitland, formerly Wallis Plains, is $210 \mathrm{~km}$.

2 Howe to Macquarie, 21 March 1820, SRNSW Reel 6049, 4/1744. 
The trope of the European explorer overcoming the barriers of a hostile Australian environment through their own ingenuity and perseverance is common in traditional colonial history. More recently, historians including Henry Reynolds, Greg Blyton and Tiffany Shellam have recognised and explored the assistance provided to European parties by Aboriginal guides, yet this still remains largely overlooked in popular understandings of Australian exploration. ${ }^{3}$

Aboriginal people had worked alongside Europeans in a wide range of roles and capacities ever since Europeans formed the colony of New South Wales in 1788. Henry Reynolds has noted that in the colonial period the exchange of labour was one of the most important elements in the relationships between Aboriginal people and Europeans. However, the relationship was never equal, with Aboriginal people making profound cultural adjustments to adapt to the new and often dangerous circumstances they found themselves in. For those Aboriginal men who worked as guides, additional dangers were ever present as they led Europeans into the often unfamiliar territory of neighbouring peoples, where cultural transgressions or misunderstandings could end in confrontations and attacks. However, while the European explorer was central to the theme of a developing nation, there was 'no discursive room left for Black pioneers', despite Aboriginal guides having been part of the explorer and settler experience from the first days of the colony. ${ }^{4}$

This chapter explores the role of Aboriginal guides in the Hunter Valley between 1818 and 1830, covering the closure of the penal station at Newcastle and establishment of free settlement in the valley. During these years the overland expeditions from Windsor, on Sydney's western fringe, forged routes through the mountains between the Hawkesbury and the Hunter rivers and the occupation of the alluvial river flats and prime farming land by European settlers took place. Although there are few sources that offer the Aboriginal perspective, through close reading of the letters, journals and diaries of the first wave of Europeans in this area, the hidden story of the

3 For recent examples of re-examinations of the relationships between European explorers and Aboriginal guides, see Reynolds 2000; Blyton 2012; Smith 2010; Shellam 2009; Macqueen 2004; Flannery 1998; Baker 1998.

4 Reynolds 2000: 9. 
Aboriginal guides can be partially recovered and the crucial role they played in these early years of the European presence in the Hunter can be examined.

European occupation of the Hunter Valley began in the first years of the nineteenth century, and Aboriginal people working as guides, interpreters and trackers were integral to it from the start. In 1801 the first official survey party of the Hunter River led by Lieutenant James Grant on the Lady Nelson included Bungaree, an Aboriginal man already well known in the colony for his skills as an interpreter and intermediary. ${ }^{5}$

Bungaree was what Reynolds refers to as a 'professional guide': someone who lived close to or in the European settlements and who was employed full time with an exploratory party. These guides derived their expertise through a combination of traditional knowledge and an understanding of European culture and language. These men - and they were most often men - retained important bushcraft skills such as tracking and hunting as well as path-finding, being able to read the landscape in unfamiliar territory and following the most desirable route. They could act as interpreters or intermediaries through their knowledge of neighbouring language or via an appreciation of traditional customs and diplomacy. ${ }^{6}$ The translation of these skills back into a form that Europeans could understand and trust displayed an ingenuity and cross-cultural creativity that has often been overlooked in the history of European exploration.

Even before Bungaree, Aboriginal people were assisting Europeans in the Hunter region. In July 1796, the crew of a fishing boat wrecked north of the Hunter at Port Stephens walked into Sydney. They had been guided along a coastal path to the Hunter River and then from there onto connecting paths via Lake Macquarie and Broken Bay to the north shore of Sydney Harbour. While the account of this overland expedition as given by David Collins is short on detail, he does note that the men were accompanied by Aboriginal people for the greater part of the way. ${ }^{7}$ The wrecked fishermen were probably

5 Bungaree had accompanied Matthew Flinders in 1798 to Norfolk Island and again in 1799 to Hervey Bay, where he had acted as an interpreter and intermediary. He is one of the most recognised Aboriginal men of Colonial Sydney. See Smith 1992: 46-49.

6 Reynolds 2000: 34.

7 Collins 1975: 489. 
escorted through country before being handed on to new guides as they proceeded further south, ensuring their safe passage through neighbouring territories down the coast.

Between 1804 and 1822, Newcastle operated as a penal station, during which time it functioned as both a place of banishment and a place of industry. Convicts were employed in its coal mines, burning lime and cutting cedar and other timbers in the forests along the river, and the prevention or recapture of runaways was of primary concern to the authorities there. Aboriginal men were employed as guides and trackers by successive Commandants to discourage convicts from absconding throughout the operation of the penal station. ${ }^{8}$ In August 1804 the then Commandant, Charles Menzies, paraded the recaptured runaway James Field in front of the convict population at Newcastle as a warning. Field, starved and wounded by spears, was the sole survivor of three who had absconded from Sydney. ${ }^{9}$ The use of Aboriginal trackers at the penal station resulted in Aboriginal people being the subject of convict hostility, with a number of fatal encounters recorded in and around Newcastle. ${ }^{10}$ However, Aboriginal men were also employed as guides to take official parties into the surrounding bushland on kangaroo hunts or fishing expeditions. In 1821 the former commandant James Wallis, in charge at Newcastle from 1816 until 1818, reminisced about his Newcastle friend and guide Burigon:

There are scenes in all our lives to which we turn back to with pleasurable tho perhaps with a tinge of melancholy feelings and I now remember poor Jack (Burigon) the black savage ministering to my pleasures, fishing, kangaroo hunting, guiding me thro trackless forests with more kindly feelings that I do many of my own colour, kindred and nation ... ${ }^{11}$

In this short passage, Wallis outlines the main reasons that Europeans employed guides, not least to guide them through the seemingly trackless forests, while also reflecting on the close personal bond that had grown between the two men. The 'trackless forest' was of course

8 An earlier attempt had been made to establish a penal station at the mouth of the Hunter River in July 1801. This was abandoned by February 1802. See Governor King Letters, Re: Newcastle 1801-1805, SLNSW MLMSS 582.

9 King to Hobart, 14 August 1804, HRA Series I, Vol. V: 111-115.

10 Blyton 2012: 94.

11 James Wallis, Album of original drawings ca1817-1818, SLNSW PXE 1070. 
a misnomer, for while looking like a wilderness to most Europeans the bush was criss-crossed with pathways and tracks used by Aboriginal people to negotiate their way across the country. ${ }^{12}$

While the penal station operated, there was very little formal exploration of the Hunter Valley beyond the margins of the settlement. It was not in the interest of the commandants for the bush to become a known place to the convict workers hemmed in by it. Yet some convicts did become familiar with the bush: the convict timber gangs were, by the very nature of their work, exploring the bush and moving through the forests. Ironically, the timber gangs reported less runaways than the convict gangs working in the settlement. One reason given at the time by Commandant John Purcell in 1810, and again by James Morisset in 1819, was that they chose their most dependable convicts to work in these gangs. Although the work was hard, the convicts were away from the scrutiny of the settlement, which Morisset claimed they preferred. ${ }^{13}$

During the years of the penal station's operation, Aboriginal guides were used primarily to assist the guards recapture absconding convicts. However, with the closure of the station, their role shifted to assisting European explorers and settlers entering the Hunter Valley. This was the period beginning with the discovery of an overland route from Windsor by Howe in 1819-1820 and culminating in the allocation of land grants to European settlers.

John Howe is credited with the discovery of the overland route that linked the settlements on the Hawkesbury to the Hunter Valley. Howe made two journeys to the river, the first in October-November 1819, when he and his party reached the Hunter River close to the presentday village of Jerrys Plains, and the second in March 1820 when they emerged out of the mountains near what is now Singleton. On the first expedition, Howe did not know what river he had come across, and assumed he was further north, close to Port Stephens. Through a combination of lack of supplies, fatigue and concern over the possibility of Aboriginal attack, he turned back without exploring further. It was only when he followed the river downstream on the

\footnotetext{
12 Needham 1981: 4.

13 Purcell to Campbell, 6 July 1810, SRNSW Reel 6066, 4/1804. Morisset evidence to Commissioner Bigge, Bonwick Transcripts, Box 1: 459. Also Turner 1973: 59.
} 
second trip and came across a convict timber-getting camp at Wallis Plains, working out of the Newcastle station, that he realised he was on the Hunter River. ${ }^{14}$

Howe was following in the footsteps of two earlier attempts to cross the mountains from Windsor, one by William Parr in November 1817 and another by Benjamin Singleton in April-May 1818. Both Parr and Singleton had set out with the intention of finding a new route from Windsor through the Blue Mountains to Bathurst, but had each headed north-west towards the Hunter. Parr set out without an Aboriginal guide and soon became disorientated in the steep valleys and mountains around the Putty area. His way was blocked by thick brush and bushfires, which, coupled with a shortage of rations, saw him abandon his expedition. ${ }^{15}$

Singleton did have an Aboriginal guide, but also turned back near the Putty area, around 100 kilometres from his start point. Although Singleton's party reached Putty in half the time of Parr, their journey beyond was similarly hampered by thick brush and a struggle to find water. ${ }^{16}$ Singleton's guide was unnamed in his journal of the expedition, but the failure of the party to penetrate beyond Putty suggests that he may have been unfamiliar with the territory he was being asked to enter, deliberately misdirecting the party to avoid a confrontation or a sacred place, or unwilling to go further into another group's country. On the night of 5 May, Singleton's camp was attacked by a group of Aboriginal men. Singleton wrote:

about 8 o'clock Disturbed by the Voices of Natives Cracking of Sticks and Rolling big rocks, stones down towards us every man of us arose and fled from the fire secreting ourselves behind trees with our guns and ammunition where we could have a view of the fire Doubting if we staid by the fire every Man was lost spent the Whole of the Night in that Condition Raining very Hard the Native whom we had with us was timid than any of us saying he was sure we should be killed. ${ }^{17}$

Despite these alarming events and the perceived threat, no attack followed. But the next morning as the party set off they encountered a group of more than 200 Aboriginal men, clothed in skins and armed

14 Howe to Macquarie, 21 March 1820, SRNSW Reel 6049, 4/1744.

15 Parr, Journal, 1817, SRNSW Fiche 3271, 2/3623. Also Macqueen 2004: 63-79.

16 Singleton, Journal, 1818, SRNSW Reel 6047, 4/1740: 209-214.

17 Singleton, Journal, 5 May 1818, SRNSW Reel 6047, 4/1740: 212. 
with spears. One of them, a man named Mawby, spoke some English, while the rest had never seen European men before. Through his Aboriginal guide, Singleton encouraged Mawby and four others to come forward and asked them if his party could advance westward. $\mathrm{He}$ was told it was impossible due to rocky country and a lack of water. ${ }^{18}$

With communications opened the conversation went both ways, as Mawby then enquired after Singleton's purpose and to where he was heading. Through his guide, Singleton said that they were trying to get to Bathurst or find good grazing land. Mawby told them that good grass land was two days to the north-east, beside a wide river that they could not swim across, nor could they drink the water of, and that this river flowed in both directions. Singleton took this to indicate a wide, tidal river, perhaps the one that ran into Port Stephens. Yet this was as far as the expedition went. Despite now having Mawby's directions to good land, the unexpected encounter with such a large body of men had unnerved the party, especially their own Aboriginal guide. Singleton decided not to proceed, fearing that the 200 men would follow and 'betray' them for their provisions. With only five in their party, they would not be able to defend themselves. He noted that their guide 'was more in dread' than themselves, and so they turned back for Windsor. ${ }^{19}$

It is not difficult to understand Singleton's decision to turn back at this point. He was low on water, effectively lost and had been confronted by a very large group of armed Aboriginal men. However, the exact nature of the encounter, while clearly tense, is now difficult to fully interpret. The night of the stone-rolling attack, Singleton noted that they had camped at the base of the largest mountain he had yet seen, Mount Monundilla in the Hunter Range. This mountain area includes rock art and shelter sites, now well-known and documented as part of the Wollemi National Park. ${ }^{20}$ This may explain the large group of men in the area, and their rock attack may have been a warning to the party to stay away. Singleton's description of the men wearing skins, rather than having their bodies daubed in ochre or paint, suggests they were

\footnotetext{
18 Singleton, Journal, 6 May 1818, SRNSW Reel 6047, 4/1740: 212.

19 Singleton, Journal, 6 May 1818, SRNSW Reel 6047, 4/1740: 212.

20 There are over 120 recorded art sites in the Wollemi National Park. See 'Rock paintings in the Upper Hunter', www.workingwithatsi.info/content/rockpaintingsl.htm, accessed 18 March 2013; Macqueen 2004: 87.
} 
not heading to ceremony or combat and so may have been hunting or moving through the country. ${ }^{21}$ Indeed, Mawby's English skills indicate previous, prolonged contact with Europeans, or at least long enough to pick up some language. Coupled with his description of the tidal river, which was almost certainly the Hunter, this suggests that Mawby had been in contact with the penal station at Newcastle or the outlying camps around Wallis Plains. Mawby and the men were using pre-existing connections and pathways known to Aboriginal people into and out of the Hunter that were there long before Europeans began to search for them. Singleton had missed his opportunity. With his own Hawkesbury guide acting as the intermediary in the encounter, Mawby was presenting him with a local's knowledge of the way through the country.

When Howe was presented with the same opportunity, he took it. His party left Windsor in October 1819, with eight Europeans and two Aboriginal guides. One of his guides was identified by the European name Myles and would have been well known to Howe, and probably the rest of his party. ${ }^{22}$

Howe was Chief Constable in Windsor and in 1816 had been involved in the suppression of Aboriginal attacks in the area. In July 1816, William Cox, the magistrate at Hawkesbury River, wrote a memorandum to Governor Macquarie outlining recent violence between Aborigines and settlers and set out a series of actions recommended to protect the settlement. Cox also named eight Aboriginal men whom he considered dangerous, four of whom he described as the most notorious. At the top of this list of four was a man named Miles. ${ }^{23}$

Acting on Cox's recommendations, Governor Macquarie made it known that following the attacks along the Hawkesbury and Nepean rivers, and despite the offer of clemency to those Aboriginal men who would surrender, 10 leaders were still urging their followers to commit attacks. The 10 were described as being 'far more determinedly hostile and mischievous, who by taking the lead have lately instigated their deluded followers to commit several further atrocious acts of barbarity

\footnotetext{
21 Attenbrow 2010: 110.

22 Howe to Macquarie, 15 May 1820, SRNSW Reel 6050, 4/1747.

23 Cox to Macquarie, 19 July 1816, SLNSW, DLADD 81: 187. Howe was also named in this report as one of the constables involved in escorting 'friendly natives' back to Sydney at the end of the action in November 1816: 193.
} 
on the unoffending and unprotected settlers and their families'. These men were therefore to be apprehended by anyone who came across them. Or, if this proved too difficult, citizens of the colony, be they 'free men, prisoners of the crown or friendly natives', were at liberty to kill the men using such means as was in their power. ${ }^{24}$ Myles was identified as one of these 10 men. ${ }^{25}$

By November several on the list had been killed or captured. Macquarie issued a second proclamation offering a pardon to those remaining men who surrendered. The inclusion of Myles in Howe's party suggests he was reconciled with and had been accepted by the Europeans. Presumably, he had come into the settlements sometime after Macquarie's proclamation and his bush skills, so feared during the attacks in 1815-1816, were now recognised as being a valuable and necessary inclusion in any exploratory party. Whatever nervousness existed among the Europeans travelling into the uncharted bush with an identified resistance leader, or indeed with Myles as he set off with men who had put his name on a death list, was seemingly put aside.

Myles guided the party beyond Putty, where it appears they ran into the same problems Parr and Singleton had encountered. Instead of blundering on, Howe sent Myles and another man out to search for a local guide. Unsuccessful the first day, he sent them again, writing in his journal that he had 'sent two Natives out for a Native guide as we could proceed no further in the direction I wanted to go' ${ }^{26}$

By sending Myles out to find local guides, Howe was displaying a more nuanced understanding of the way Aboriginal cultural practice and bushcraft operated. As Singleton found out, not all Aboriginal people were familiar with country outside their own, nor were they necessarily welcome in it. Myles may have advised Howe of the fact that they needed a local connection, maybe as much for guidance as for right of passage. Henry Reynolds argues that local knowledge was

24 Sydney Gazette and New South Wales Advertiser, 27 July 1816: 1. It should be noted the change in spelling from Miles in Cox's report to Myles in the Government Notice. Myles remains the spelling in official reports and in Howe's letters to Macquarie.

25 The name Myles probably derived from the Sydney language Aboriginal word Mi-yal which meant a stranger, according to a word list compiled by David Collins in his An Account of the English Colony in New South Wales (Collins 1975: 507). See also Ford 2010: 75, 122. Ford shows from blanket distribution lists that Myles's Aboriginal name was Mioram and adds that the English version, Myles, was taken to mean 'wild' or undomesticated.

26 Howe, Journal, 1819, SRNSW Reel 2623, 2/8093. 
one of the most valuable resources that European explorers could rely on, providing an intimate knowledge of the country through which they were passing. ${ }^{27}$

The local guide, Murphy, led the party through the mountains and out onto the flood plains of the upper Hunter River. However, the route was at times arduous and difficult: the packhorses had to be unloaded and there were lengthy detours around swamps and bogs. Further, the party did not penetrate far into the valley, as Myles and Murphy refused to go on after it was discovered they were under surveillance by a group of Hunter Valley men. On their return, they visited the Aboriginal camp that Murphy had come from. There an older Aboriginal man, Whirle, admonished Murphy for taking them the hard way and told Howe he knew a quicker and easier route. ${ }^{28}$ Why two different routes were eventually shown to Howe is unclear, although a number of interpretations can be made. Maybe Murphy was deliberately trying to mislead Howe and his group or lead them away from sacred sites, or attempting to discourage future European excursions into the area by taking them on such a difficult path. Alternatively, he might have been taking a higher track to enable him to cautiously approach the neighbouring country, or he may not have even been aware of the route proposed by the older Whirle. It is unlikely Murphy did not know Whirle's pathway, which passes close by to Baiame's Cave, an important initiation and ceremonial site, and suggests that caution may have been the real reason. ${ }^{29}$

The advantages of having the Aboriginal guides are clear in these accounts. The guides enabled Howe to move more quickly through the country, warned him of the potential danger of being in another group's country, and resulted both in discovery and knowledge of an easier route.

Three weeks after their return to Windsor, in what appears to be a first for the colony, Myles, his brother Mullaboy and 'a small number of natives' were provisioned, equipped and armed with muskets by

27 Reynolds 2000: 25.

28 Howe, Journal, 11 November 1819, SRNSW Reel 2623, 2/8093; Howe to Macquarie, 27 December 1819, SRNSW Reel 6068, 4/1743. It is not known where the names Whirle and Murphy originated from, whether they were attributed by Howe or through previous encounters with Europeans.

29 Moore 1981: 397. 
order of Governor Macquarie, and sent back out to meet Whirle and another man, Bandagran, and follow their track to the river. ${ }^{30}$ Nineteen days later the all-Aboriginal exploring party returned and reported to Howe that they had followed an easier path through the mountains to the river. This was the path that Howe took on his second expedition in 1820, following Myles back through the ranges along the Aboriginal pathway of Whirle. The Putty Road, which today connects Windsor to Singleton, closely follows the route. For his efforts, Myles was presented with a breast plate and musket. Howe was given a grant of 700 acres on the banks of the Hunter River after claiming the discovery of the overland way as his own. ${ }^{31}$

Myles's rehabilitation in the eyes of the Europeans was complete. In the space of four years, he had gone from hunted rebel warrior to trusted guide and rewarded explorer. Howe's use of and trust in Myles speaks of the personal relationship that had developed between the two men that was necessary for the successful collaboration of explorer and guide. A high level of trust was needed on both sides for these forays into unknown territory.

While the advantages for Europeans of using guides is clear enough, why would Aboriginal men agree to go? Without the voice of the guides themselves, we can only speculate on their motivations, but the experience of Myles may offer some clues.

Myles had been, until recently, a wanted man. The very name he was given by Europeans suggests someone on the outer - Myles being a derivative of the Aboriginal word Mi-yal, meaning stranger in the Sydney language. ${ }^{32}$ Gaining the confidence of Europeans via a successfully guided expedition would have been an advantage for Myles on the potentially volatile frontier where he lived. Being with an armed party of Europeans while heading into another group's territory may also have been a strong motivation. Tiffany Shellam's examination of the relationships formed between Europeans and the King Ya-nup in south-west Western Australia in the 1830s demonstrates the recognition that Aboriginal people had of the

\footnotetext{
30 Howe to Macquarie, 27 December 1819, SRNSW Reel 6068, 4/1743.

31 Governor Macquarie Correspondence, 18 September 1820, SLNSW CY1449 C330.

32 Collins 1975: 507. Similarly, the Wiradjuri word mayol was also translated as meaning wild Aborigine by John Fraser in 1892. See Fraser 1892: Appendix 1, 98.
} 
potential advantages of working alongside European explorers. ${ }^{33}$ Aboriginal guides recognised the advantage that new knowledge of distant country could have for them amongst their own people and their neighbours. Knowledge about new country and new people was a valuable commodity that could be traded and benefited from, and could elevate a person's status in the eyes of both their own kin and those of the Europeans. ${ }^{34}$

Outside of security and status, guiding provided access to European goods and weapons. Clothes, tobacco and food were routinely traded by European explorers to Aboriginal helpers and guides in return for their service and served as a strong incentive. In a few cases, as seen with Myles, some were rewarded with muskets which would have been a highly prized acquisition. Some local guides, like Murphy or Whirle, may also have been motivated to assist Europeans as a means of steering them away from local sacred sites or to facilitate their rapid movement through and out of their country. ${ }^{35}$

However, the role of the guide was also a transitory one. The guide was only useful at the edge of the frontier, at the point in time when Europeans were pushing beyond their known boundaries. On his return to Windsor after his second expedition, Howe blazed the trees, thereby marking a clear path for others to follow. ${ }^{36}$

Pathways made through the bush by Howe and others hastened the closure of the Newcastle penal station. Four months after Howe's expedition, the Commandant Morisset complained that four convicts in a cedar party had run from Paterson's Plains, following the path made by Howe. ${ }^{37}$ Another track blazed by the Reverend George Augustus Middleton, known as the Parsons Road, also became a wellused escape route from December 1821. ${ }^{38}$ Middleton had travelled overland to Newcastle with 173 head of cattle, guided by an unnamed Aboriginal companion. ${ }^{39}$

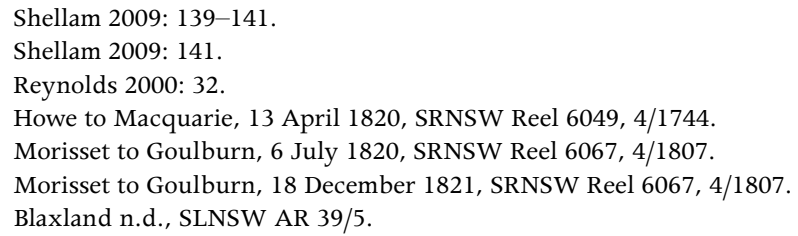


With tracks marked, the role of the professional guides was effectively finished for journeys to the Hunter, but in the valley itself a new role for local guides began to emerge. Europeans arriving in the Hunter Valley to take land grants after 1821 were as lost in the seemingly trackless wilderness as Wallis had claimed to be in 1816. Many of the emigrant farmers travelled to Newcastle via ship from Sydney, before heading upriver to take up their land.

For those whose grants were further inland, away from the settled areas, the bush was still a formidable barrier, through which they had to pass before they could establish themselves and begin farming. Although Howe had reported fine, open country where he had entered the valley, around the Wallis Plains and Paterson's Plains sections of the river, the bush was thick and impenetrable. ${ }^{40}$

One of the first emigrants was John Brown, who arrived in Newcastle around May 1822 with a grant of 2,000 acres. An Aboriginal guide took Brown to his grant. This man told him the name of the place was Bolwarra, which reportedly meant 'flash of light', and which Brown adopted as the name of his estate. ${ }^{41}$

Most settlers could get to Wallis Plains by boat, but from there further travel was overland. At this starting point, a local pool of guides appears to have operated for a short time taking new settlers inland. James Mudie, a settler in the Patricks Plains area, was guided from Wallis Plains in August 1822. Heading inland, Mudie wrote to the Colonial Secretary requesting that if the assistant surveyor would provide him with:

the necessary particulars of that part of the country called St Patricks Plains, so as to enable me to proceed through the bush, I would make an attempt to find it by the assistance of some of the Natives. ${ }^{42}$

Yet, despite their reliance on these men, few Europeans detailed how they actually procured the services of the guides.

In mid-1823, the brothers Robert and Helenus Scott, who had recently arrived in the colony, travelled to the Hunter to claim their land grant. The brothers hired a horse from a Wallis Plains farmer named Morgan

\footnotetext{
40 Dangar, Survey Field Book No. 193, 1822, SRNSW 2/4837: 31.

41 The Australian, 28 February 1834: 3.

42 Mudie to Colonial Secretary, 25 January 1823, SRNSW R6067, 4/1809.
} 
before heading inland towards their grant without a guide. On their first morning as they were preparing to pack up camp, a young Aboriginal boy appeared out of the bush. Scott's servant, also named John Brown, kept a journal in which he related the first meeting:

we asked him what his name was and where he was going, he said the White men call me Ben Davis, and he was going along with us, for Binghi Morgan sent him, which we was very glad of for we had been trying to get one of the Blacks to go with us but none of them happened to be at the settlement at the time, and this boy happened to go there soon after we had left and Morgan had sent him after us. ${ }^{43}$

The guide, Ben Davis, had taken or been given the name of the convict farmer Benjamin Davis, one of the first Europeans to settle along the Hunter River around Wallis Plains. Davis had been allocated a small plot on the river in 1814 under Governor Macquarie's plan to encourage good behaviour amongst convicts at Newcastle and to make the penal station self-sufficient. Although Davis was still living at Wallis Plains on his farm in 1823, the guide was sent by Morgan. The best known Morgan at Wallis Plains at this time was the emancipist Molly Morgan, yet Brown identifies Morgan as an Englishman. He may have been associated with Molly Morgan, however, as her influence in the area was such that the unofficial name for the settlement in the first half of the 1820s was Molly Morgan's. ${ }^{44}$ Whoever organised for Ben Davis to pursue the Scott party through the bush, the arrangement suggests a close collaboration between Aboriginal people and some Europeans in the Wallis Plains area.

The labour hire service apparently provided by Morgan and Ben Davis displays aspects of what Richard White has called the 'middle ground' in frontier cross-cultural relations. In his work on the northwest frontier of colonial America, particularly around the Great Lakes district, White proposed a period of coexistence between French fur traders and the different American native nations that lived in the area. White argues that for a period both Europeans and the American nations lived in a mutually comprehended and advantageous world

43 Anonymous diary by a servant of the Scott family, 8 August 1821-March 1824, SLNSW MLMSS 7808: 55-56.

44 Wood 1972: 243. It is also worth noting that the word Binghi used by Ben Davis to identify Morgan could be Brown's spelling of the local word Biggai, identified by the Reverend Lancelot Threlkeld as meaning elder brother or an affectionate form of address for brother. If so it may identify a closer relationship between Ben Davis and Morgan. See Fraser 1892: 203. 
immediately behind the frontier of the European empire. While it was still a violent place, the middle ground was also a place where both sides cooperated to some degree to accommodate each other for mutual benefit. ${ }^{45}$ A central aspect was the inability of either side to gain what they wanted through the use of force, thereby making it necessary to come to some arrangement to achieve each other's objectives. While they acted out of interests derived from their own culture, those operating in this space also had to convince people of another culture that any mutual action was fair and legitimate. ${ }^{46}$ For Aboriginal guides, their work allowed an aspect of protection while also keeping them in contact with their country, while their skills and knowledge of the land helped Europeans move through it and could assist them in avoiding confrontations with other Aboriginal people met along the way. A middle ground was only possible when the two sides were evenly balanced, and so was short lived in the Hunter Valley. It appears that while Morgan was acting as an agent or a go-between for newly arrived colonists with no experience of the bush or any existing relationships with Aboriginal people, Aboriginal people in the area were also taking advantage of Morgan's position to secure employment as guides and gain access to European goods. A local economy had developed to serve the needs of settlers in the short period before the valley was mapped out and made known to Europeans.

Brown continues:

We set of [sic] with Ben Davis as a guide and he seemed very much pleased, and kept talking all the way he went but we did not understand him but by what we could make out he was telling us about the country. ${ }^{47}$

Brown's description of Ben Davis telling the Europeans about country is a tantalising glimpse of what may have been said by Aboriginal people about their relationship to the Hunter Valley, as well as the misconception of the European view. Brown gives no further information on what he thought Ben Davis was telling them but, through physical descriptions of the land added by Brown as they travelled towards their grant, it is likely he took Ben Davis's account as just that,

45 White 1991: $\mathrm{x}$.

46 White 1991: 52.

47 Anonymous diary by a servant of the Scott family, 1821-24, SLNSW MLMSS 7808: 56. 
a simple, physical outline of their surroundings. However, country meant different things to Aboriginal people than it did to Europeans. Country was a complex idea, an interweaving of physical, territorial and cultural understandings of a place. While it could indeed refer to the physical landscape, country was more multidimensional as it also identified the people who lived in or managed an area, the animals, the waterways, the earth, the soil, the sky and the underground. ${ }^{48}$ Everyone had a country, an area of land defined by their sites and knowledge and under the care and management of a particular group. In their own country, a person might see the landscape shaped through their understanding of the Dreaming and filled with sites and stories that explained the logic of the place. ${ }^{49}$ It is possible therefore that, rather than simply giving a physical description of the land, Ben Davis was offering a narration of country, imparting some of the deeper connections and knowledge that helped him navigate physically and spiritually through the Hunter Valley.

Ben Davis stayed with the party three days, until they reached Patricks Plains (Singleton). He acted as an intermediary and interpreter on two separate occasions along the way and later accompanied Robert Scott kangaroo hunting. These roles reflect the actions of earlier guides like Bungaree and Myles who helped negotiate through other people's country but at a local level. On one occasion when Ben Davis acted as an intermediary, he acknowledged that he knew the Aboriginal man who led a group that had approached the party. Ben Davis remarked that the man, identified as Mytie, was a 'very good fellow' and Brown was soon on friendly terms with the whole group, digging yams and fishing in the river with them..$^{50}$ Mytie himself said he belonged to the 'Womby tribe', the people who lived in the mountains and valleys south of Patricks Plains, through which Howe had passed in 1820. This geographical positioning illustrates the interconnectedness of the Aboriginal groups in the lower Hunter Valley and surrounding

\footnotetext{
48 Rose 1996: 8.

49 Gammage 2011: 139.

50 Anonymous diary by a servant of the Scott family, 1821-24, SLNSW MLMSS 7808: 59-60.
} 
mountains, as previously hinted at by Mawby. Mytie's group stayed several days, but when the Scotts moved onto their grant at Glendon, Mytie and Ben Davis left them. ${ }^{51}$

Brown left Glendon after 25 weeks, heading to Newcastle to pick up a ship back to Sydney and eventually to England. Making his way to Wallis Plains, he once again employed an Aboriginal guide to help him get to Nelsons Plains where he could board a boat downriver to Newcastle. Brown agreed to pay the man with tobacco when he arrived safely at his destination. ${ }^{52}$

Brown only employed a guide for the unknown portion of his return trip to Newcastle, between Wallis Plains and Nelsons Plains. The area between Wallis Plains and the farm at Glendon, where Ben Davis had guided Brown six months before, was no longer an unknown landscape to Europeans, as tracks made by settlers began to connect the farms and outposts.

The land around Nelsons Plains, however, with thick brush forest and swampy ground, remained an area that Europeans treated with caution. Brown's employer Robert Scott was still finding his way in the bush here as well. On 15 October 1823, he wrote in his journal:

M \& I agreed to walk to Nelsons Plains across the country if we could have got a Native to show us the way ... [However,] it seems there is to be a grand Cabbra Feast somewhere in the neighbourhood and nothing in the world could induce them to be absent from such an entertainment ... As we could not get a Native, Mitchell and I were afraid to trust ourselves in the forest, therefore we only walked to the same spot we disembarked last night ... ${ }^{53}$

Scott's account gives us a glimpse not just at the need for guides on even short excursions in some areas, but also at the motivations of Aboriginal people to join or not join an expedition. In this case, the advantages of assisting Scott on what was a relatively small journey were not enough to outweigh the cultural benefits of the cobbra feast and associated gathering.

51 Anonymous diary by a servant of the Scott family, 1821-24, SLNSW MLMSS 7808: 55-61. Ben Davis stayed in the Hunter Valley around Wallis Plains. He was identified by his name Munnion in a blanket distribution list in June 1834 at Paterson on the Hunter River close to Wallis Plains. See Colonial Secretary's Correspondence, Special Bundles, SRNSW 4/6666B.

52 Anonymous diary by a servant of the Scott family, 1821-24, SLNSW MLMSS 7808: 65.

53 Scott, Journal, 15 October 1823, SLNSW MLMSS A2266. 
As with professional guides assisting exploratory parties, the use of local men as guides, employed as required by settlers heading towards their grants was also a short-term proposition. Between 1822 and 1825, the Assistant Government Surveyor Henry Dangar was surveying the valley for settlers and grant holders. His survey work made the place increasingly familiar to Europeans and reduced the need for guides in the settled areas. There is no evidence that Dangar himself utilised the skills of Aboriginal guides during these surveys, as neither his field books nor the detailed letters to the Surveyor General regarding his progress make any mention of them. He may have deliberately omitted reference to them to enhance his own reputation as a surveyor; however, his description of a young Aboriginal guide in an expedition to find a passage from the upper Hunter Valley to the Liverpool Plains in October 1824 suggests he was not averse to recognising their assistance. ${ }^{54}$ Guidance was not as essential in his survey work, where he was mapping the land and marking his path as he progressed.

Dangar's surveys led to increased European penetration of the Hunter Valley. In 1828, he published a guide for emigrants, including a map compiled from his survey work that outlined the type of country in different parts of the valley and the various agricultural purposes it was suited to. Dangar, looking to profit from the emigrant market, wrote:

I trust that the Map, with the Index ... will enable persons of all descriptions to proceed to any part of the country there delineated, and there to describe with accuracy the position they wish to select. ${ }^{55}$

Dangar's map effectively ended the need for Aboriginal guides in the Hunter Valley. Nevertheless, those wishing to travel beyond the settled districts or, in some cases, even between those areas that were less frequently visited, still needed guiding, even with Dangar's map or his surveys. In the year Dangar published his map and index, some visitors to the Hunter were still employing Aboriginal guides to assist them within areas Dangar had covered. Roger Oldfield, editor of the short-lived periodical South-Asian Register, wrote of a visit to the Hunter in 1828:

54 Surveyor General Letters Received 1822-55, SRNSW Reel 3060, 2/1526.1; Dangar Survey Field Book No. 221, 1824, SRNSW 2/4861.

55 Dangar 1828: v. 
In the course of our progress along the Hunter, we engaged a black fellow to be our guide, in which capacity the blacks are of a most essential service. A map and compass are useful: but the local maps, which are obtained directly or indirectly from the Colonial Surveyors, have very few natural boundaries laid down, for the guidance of a stranger; and the compass, is a very uncertain benefit, when standing on the margin of an extensive morass, or when fixed in the dilemma of a thicket. ${ }^{56}$

While the use of guides to take Europeans inland to their land was in decline by the late 1820s, Aboriginal men continued to be employed in the Hunter Valley throughout the 1830s and into the 1840s to take Europeans on hunting or fishing expeditions, as well as running messages across country and acting as guides for botanical and natural history collectors. ${ }^{57}$ Although strangers and visitors still employed Aboriginal guides into the 1830s for collecting trips or more remote journeys, the role of the guides was beginning to wane.

This chapter demonstrates that the use of guides for the exploring parties and later for settlers was widespread in the Hunter Valley, as it was throughout colonial Australia. Although their role has been largely forgotten or overlooked in colonial histories, Aboriginal assistance had been essential for the exploration as well as the economic development of the region, and was actively sought out by Europeans arriving in the valley. By re-examining the journals, letters and reports of the first wave of Europeans, the story of the guides, intermediaries and interpreters that they relied on can be resurrected. As Greg Blyton has noted, these Aboriginal men while advancing the invasion of their country were also realists, responding to the opportunities presented by the European's needs, and using their traditional knowledge and skills to maximise their own chances of survival in a rapidly changing environment. ${ }^{58}$ 


\section{References}

Anonymous diary by a servant of the Scott family, 8 August $1821-$ March 1824 (written after 1825), with notes, 1832, State Library of NSW [SLNSW] MLMSS 7808 (Safe 1/403).

Attenbrow, Val 2010, Sydney's Aboriginal Past: Investigating the Archaeological and Historical Records, second edition, UNSW Press, Sydney.

Baker, Don 1998, 'Exploring with Aborigines: Thomas Mitchell and his Aboriginal guides', Aboriginal History 22: 36-50.

Blaxland, John de Marquet, n.d., 'Discovery of the road to Coal River', SLNSW AR 39/5.

Blyton, Greg 2012, 'Aboriginal guides of the Hunter region 1800-1850: A case study in Indigenous labour history', History Australia 9(3): 89-106.

Brown, John 1821-24, Anonymous Journal of a Servant of Robert Scott, SLNSW MLMSS 7808.

Collins, David 1975 [1798], An Account of the English Colony in New South Wales, vol. 1, Brian Fletcher (ed.), A.H. \& A.W. Reed, Sydney.

Colonial Secretary's Correspondence, Special Bundles, SRNSW 4/6666B.

Cox, William to Governor Macquarie, 19 July 1816, Documents relating to Australian Aborigines 1816-1853, William Dixon Collection, Mitchell Library, SLNSW DLADD 81, p187.

Dangar, Henry 1822, Surveyors Field Book, No. 193, State Records Authority of NSW (SRNSW) 2/4837.

— 1824, Surveyors Field Book, No. 221, SRNSW 2/4861.

- 1828, Index and Directory to Map of the Country bordering upon the River Hunter; the lands of the Australian-Agricultural Company; with the ground-plan and allotments of King's Town, New South Wales, British Library Historical Print Collection, London.

Flannery, Tim 1998, The Explorers, Text Publishing, Melbourne. 
Ford, Geoff 2010, 'Darkingung Recognition: An Analysis of the Historiography for the Aborigines from the Hawkesbury-Hunter Ranges Northwest of Sydney', MA (Research) thesis, School of Philosophical and Historical Inquiry, Department of History, University of Sydney.

Fraser, John 1892, An Australian Language: As spoken by the Awabakal, the people of the Awaba or Lake Macquarie; being an account of their language traditions and customs by L.E Threlkeld; re-arranged, condensed and edited with an appendix by John Fraser, Government Printer, Sydney.

Gammage, Bill 2011, The Biggest Estate on Earth: How Aborigines Made Australia, Allen \& Unwin, Crows Nest, NSW.

Governor King Letters, Re: Newcastle 1801-1805, SLNSW, MLMSS 582.

Governor Macquarie Correspondence, SLNSW, CY1449 C330.

Gunson, Niel (ed.) 1974, Australian Reminiscences and Papers of L.E. Threlkeld: Missionary to the Aborigines 1824-1859, Australian Institute of Aboriginal Studies, Canberra.

Howe, John 1819, Journal of John Howe Expedition from Windsor to the Hunter River in 1819, NSW Surveyor General Field Books, SRNSW Reel 2623, 2/8093.

Howe, John to Governor Macquarie, 27 December 1819, Colonial Secretary's Correspondence, SRNSW Reel 6068, 4/1743.

21 March 1820, Colonial Secretary's Correspondence SRNSW Reel 6049, 4/1744.

13 April 1820, Colonial Secretary's Correspondence, SRNSW Reel 6049, 4/1744.

15 May 1820, Colonial Secretary's Correspondence, SRNSW Reel $6050,4 / 1747$.

King, Governor to Lord Hobart, 14 August 1804, Historical Records of Australia, Series I, Vol. V: 111-115. 
Macqueen, Andy 2004, Somewhat Perilous: The Journeys of Singleton, Parr, Howe, Myles \& Blaxland in the Northern Blue Mountains, A. Macqueen, Wentworth Falls, NSW.

Moore, David R. 1981, 'Results of an archaeological survey of the Hunter River Valley, New South Wales, Australia: Part II Problems of the lower Hunter and contacts with the Hawkesbury Valley', Records of the Australian Museum 33(9): 388-442.

Morisset, James T., Commandant to Frederick Goulburn, 6 July 1820, Colonial Secretary's Correspondence, SRNSW Reel 6067, 4/1807.

18 December 1821, Colonial Secretary's Correspondence, SRNSW Reel 6067, 4/1807.

Mudie, James to Colonial Secretary, 25 January 1823, SRNSW Reel $6067,4 / 1809$.

Needham, William J. 1981, Burragurra: Where Spirit Walked: The Aboriginal Relics of the Cessnock-Wollombi Region in the Hunter Valley of NSW, Bill Needham, Cessnock, NSW.

Oldfield, Roger (ed.) 1828, The South-Asian Register, No. 2, January 1828: 107.

Parr, William 1817, 'Journal and Station Book of a trip to the westward (Hawkesbury Valley)', Colonial Secretary's Correspondence, Special Bundles, Logs, Diaries and Journals of Exploration, SRNSW Fiche $3271,2 / 3623$.

Purcell, John to John T. Campbell, 6 July 1810, Colonial Secretary's Correspondence, Special bundles-Newcastle, SRNSW Reel 6066, $4 / 1804$.

Reynolds, Henry 2000, Black Pioneers: How Aboriginal and Islander People Helped Build Australia, Penguin Books, Ringwood, Vic.

Rose, Deborah Bird 1996, Nourishing Terrains: Australian Aboriginal Views of Landscape and Wilderness, Australian Heritage Commission, Canberra.

Scott, Robert 1823, Journal describing a voyage from the Hunter River to Sydney in company with Rev. Middleton, Mr Bowman and Mr Dixon, vol. 7, SLNSW MLMSS A2266. 
Shellam, Tiffany 2009, Shaking Hands on the Fringe: Negotiating the Aboriginal World at King George's Sound, UWA Publishing, Perth.

Singleton, Benjamin 1818, Journal, Colonial Secretary's Correspondence, SRNSW Reel 6047, 4/1740.

Smith, Keith Vincent 1992, King Bungaree: A Sydney Man Meets the Great South Pacific Explorers, 1799-1830, Kangaroo Press, Kenthurst, NSW.

2010, Mari Nawi: Aboriginal Odysseys, Rosenberg Publishing, New South Wales.

Surveyor General Letters Received 1822-55, Henry Dangar Letters, March 1822-August 1824, SRNSW Reel 3060, Item 2/1526.1.

Sydney Gazette and New South Wales Advertiser.

The Australian.

Turner, John (ed.) 1973, Newcastle as a Convict Settlement: The Evidence before J.T. Bigge in 1819-1821, Newcastle History Monographs No. 7, Newcastle Public Library, Newcastle.

Wallis, James, Album of original drawings cal817-1818, SLNSW PXE 1070.

White, Richard 1991, The Middle Ground: Indians, Empires and Republics in the Great Lakes Region 1650-1815, Cambridge University Press, New York.

Wood, Walter Allan 1972, Dawn in the Valley: The Story of Settlement in the Hunter River Valley to 1833, Wentworth Books, Sydney. 
This text is taken from Brokers and Boundaries: Colonial Exploration in Indigenous Territory, edited by Tiffany Shellam, Maria Nugent, Shino Konishi and Allison Cadzow, published 2016 by ANU Press, The Australian National University, Canberra, Australia. 